\title{
The Industry International Competitiveness
}

\section{Analysis between China and South Asia Countries the Capacity Cooperation Path Building Based on 'One Belt One Road'}

\author{
Shushu Feng \\ International Business School \\ Yunnan University of Finance and Economics \\ Kunming, China \\ shushufeng@gmail.com
}

\author{
Ersi Liu* \\ International Business School \\ Yunnan University of Finance and Economics \\ Kunming, China \\ liuersi309@126.com
}

\begin{abstract}
This paper analyzes the international trade status quo between China and 8 South Asia countries by utilizing UN Comtrade data from 2011 to 2015. By comparative advantage and competitive advantage analysis, it studies the industry international competitiveness of the 9 sectors of China and the South Asian countries. It is concluded that manufacturing is the main international competitiveness in China, which can be transferred to South Asia countries. The primary goods are the sectors that South Asia countries have advantage, which is the main point of cooperation with China.
\end{abstract}

Keywords-South Asia countries; capacity cooperation; industry international competitiveness;

\section{INTRODUCTION AND LITERATURE REVIEW}

After the 2008 financial crisis that spread the world, China's traditional industry witnessed the excess manufacturing capacity. The economic development pace has slowed down and China's economy steps into the "new normal" phase. Under this international and domestic background, China is exploring the new trade cooperation and foreign investment methods aggressively. The "One Belt and One Road" proposed in 2013 and "Supply-side Reform" proposed in 2015 have provided a new path in international capacity cooperation, which is a way to promote mutual benefits and complementary advantages through exchange, and creates a new model that combining international industry transfer and outward foreign direct investment. Promoting the capacity cooperation can strengthen the mutual beneficial cooperation.

Industry international competitiveness plays a critical role in the capacity cooperation. Schott (2008) [3] compared China's industry international competitiveness with the developed countries using the multi-national companies' data and pointed out an approach of industrial cooperation. Zhao and Sang (2016) [7] pointed out that manufacturing industry is the main driving force to promote China's industrial competitiveness by studying the trade conditional of China and the 65 countries that sit along the One Belt and One Road.

When establishing the approaches of international capacity cooperation, relevant finance, taxation, insurance and foreign trade policies should be formulated to support the information

\footnotetext{
* Corresponding author
}

service system [4]. Similarly, Yin and Pan [6] indicated that the border provinces can coordinate with the neighboring countries to construct the industrial park and actively build international capacity cooperation forum. Yang, Li and Zhang [5] extended this approach to value chain and mentioned that the Chinese companies should construct its independent industry value chain in order to engage in the international capacity cooperation actively.

The regional definition of south asia countries and data resources

Based on the Country List of One Belt One Road issued by Chinese Academy of Social Sciences, there are 64 countries along the One Belt One Road, in which 8 countries are from South Asia. Those countries are all developing countries, which include Afghanistan, Bangladesh, Sri Lanka, Pakistan, India, Bhutan, Maldives and Nepal.

The main data source of this paper is UN Comtrade, which provides the official detailed trade statistics around the world. This study covered the trade data between China and South Asia countries from 2011 to 2015 and only focused on the trade goods. According to the SITC/Rev.3 category, the international trade goods are divided into 10 commodities, which codes ranges from 0 to 9 . It is considered that codes $0-4$ are primary goods, while codes 5-8 are manufactured goods. Based on the different sources of production sources, it is determined that codes $0-1$ are resource intensive, 2-4 are energy intensive, 5/7 are capital intensive and $6 / 8$ are labor intensive goods. Detailed category can be seen in Table I.

\section{ThE TRade Status Quo Between ChInA AND South ASIA COUNTRIES AND COMPARATIVE ADVANTAGE ANALYSIS AND COMPARATIVE ADVANTAGE ANALYSIS OF INTERNATIONAL INDUSTRY COMPETITIVENESS}

There are a number of comprehensive index systems to evaluate the industry international competitiveness. Pei and Wang [2] utilized the explicit factor and explanatory factor for the system, which the former illustrated the result of international industry competitiveness and the latter reflected the reasons of it. Jin, Li and Chen (2006) [1] studied the comparative advantage and competitive advantage of industry international competitiveness. This paper will adopt the latter 
way of research, which is the comparative advantage of the industry international competitiveness.

TABLE I. STIC/REV.3 CATEGORY

\begin{tabular}{|l|l|l|l|}
\hline Commodity Code & Commodity & Catetory & Factor Origin \\
\hline 0 & Food and live anaimals & Primary Goods & Resource Intensive \\
\hline 1 & Beverage and tabacco & Primary Goods & Resource Intensive \\
\hline 2 & Crude materials, inedible, except fuels & Primary Goods & Energy Intensive \\
\hline 3 & Mineral fuels, lubricants and related materials & Primary Goods & Energy Intensive \\
\hline 4 & Animal and vegetable oils, fats and waxes & Primary Goods & Energy Intensive \\
\hline 5 & Chemicals and related products, n.e.s. & Manufactured Goods & Capital Intensive \\
\hline 6 & Manufactured goods classified chiefly by material & Manufactured Goods & Labor Intensive \\
\hline 7 & Machinery and transport equipment & Manufactured Goods & Capital Intensive \\
\hline 8 & Miscellaneous manufactured articles & Manufactured Goods & Labor Intensive \\
\hline
\end{tabular}

\section{A. The Trade and Investment Status Quo between China and} South Asia Countries

In 2015, the total export and import volume between China and South Asia countries were \$111.3billion, which witnessed an increase of $14 \%$ than that of 2011 . This number takes up $11.13 \%$ of the total trade between China and the all the 64 countries along the One Belt One Road'. It is concluded that India is China's largest importer and exporter in South Asia, whose export and import are $\$ 58.26$ billion and $\$ 13.39$ billion respectively. Pakistan is the second largest, which accounted for 2.477 billion for import and \$16.48billion for export. The trade between China and those 2 countries has reached $64 \%$ and $17 \%$ respectively in South Asia area. Trade volume details are shown in Table II.

TABLE II. China's Trade Volume to South Asia Countrise (Unit: \$Millions)

\begin{tabular}{|l|l|l|l|l|l|l|l|l|l|l|l|}
\hline Year/Country & $\mathbf{2 0 1 5}$ & $\mathbf{2 0 1 4}$ & $\mathbf{2 0 1 3}$ & $\mathbf{2 0 1 2}$ & \multicolumn{2}{l|}{$\mathbf{2 0 1 1}$} \\
\cline { 2 - 11 } & Import & Export & Import & Export & Import & Export & Import & Export & Import & Export \\
\hline Afghanistan & 0.01 & 364.32 & 17.37 & 393.56 & 9.60 & 328.26 & 5.19 & 464.03 & 4.40 & 230.01 \\
\hline Bangladesh & 803.72 & $13,904.75$ & 760.85 & $11,783.09$ & 602.37 & $9,705.09$ & 479.73 & $7,970.09$ & 449.04 & $7,810.66$ \\
\hline Sri Lanka & 259.24 & $4,308.11$ & 247.57 & $3,792.85$ & 182.56 & $3,436.55$ & 161.96 & 3001.30 & 152.89 & $2,988.72$ \\
\hline Pakistan & 2477.07 & $16,481.15$ & $2,755.36$ & $13,246.45$ & $3,196.84$ & $11,019.60$ & $3,140.39$ & $9,276.49$ & $2,118.46$ & $8,439.73$ \\
\hline India & $13,395.98$ & $58,262.00$ & $16,358.75$ & $54,220.38$ & $16,970.27$ & $48,432.41$ & $18,797.19$ & $47,677.45$ & $23,372.28$ & $50,536.42$ \\
\hline Bhutan & 0.35 & 9.95 & 0.10 & 11.12 & 0.01 & 17.41 & 0.01 & 15.60 & 0.08 & 17.38 \\
\hline Maldives & 0.19 & 172.59 & 0.38 & 103.99 & 0.42 & 97.41 & 0.19 & 76.49 & 0.14 & 97.12 \\
\hline Nepal & 22.99 & 830.01 & $2,283.57$ & 43.25 & 53.25 & $2,210.89$ & 29.52 & $1,968.16$ & 13.86 & $1,181.23$ \\
\hline
\end{tabular}

In 2014, China's Outward Foreign Direct Investment (Hereinafter referred to OFDI) stock to South Asia countries was $\$ 8.33$ billion, which is $9.01 \%$ of the number of the 'One Belt One Road' countries in total. It is noted that the largest OFDI is directed to Pakistan, which accounted $44.87 \%$. Pakistan also enjoyed the highest growth rate of investment stock, which increased by $59.48 \%$ than 2013 . Table III gives the details of China's OFDI to South Asia countries in 2014.

\section{B. The Comparative Advantage Analysis of International Industry Competitiveness}

1) Revealed Comparative Advantage

The RCA is an index that is used to calculate the relative advantage or disadvantage of a country in a certain goods or services. It is equal to the proportion of the country's exports that are of the class under consideration (Eij/Eit) divided by the proportion of world exports that are of that class (Enj/Ent).

$\mathrm{RCA}=\frac{\text { Eij/Eit }}{\text { Enj/Ent }}$ 
TABLE III. China’s Ofdi to South Asia CoutnRIES IN 2014 (Unit: \$MiLLIONS)

\begin{tabular}{|l|l|l|}
\hline Countries & OFDI Stock & Percentage \\
\hline Afghanistan & 518.49 & $6.23 \%$ \\
\hline Bangladesh & 160.24 & $1.92 \%$ \\
\hline Sri Lanka & 363.91 & $4.37 \%$ \\
\hline Pakistan & $3,736.82$ & $44.87 \%$ \\
\hline India & $3,407.21$ & $40.92 \%$ \\
\hline Maldives & 2.37 & $0.03 \%$ \\
\hline Nepal & 138.34 & $1.66 \%$ \\
\hline
\end{tabular}

It is believed that the country have a comparative advantage in the commodity if $\mathrm{RCA}>1$, while a relatively low competitiveness will be shown if $\mathrm{RCA}<0.8$.

From the calculation in Table 4, it is concluded that China's manufacturing industry has a strong comparative advantage since the RCA index of commodity code $6,7,8$ are all more than unity. The South Asia countries have a strong advantage in ariculture exports. Although the RCA is relatively high in manufacturing industry 6 and 8 , RCA in code 7 is much lower, which indicates that the manufacturing industry is still labor intensive.

TABLE IV. The Industry International COMPETITIVENEsS ANALyysis BetweEn China ANd South Asia Countries

\begin{tabular}{|l|l|l|l|l|l|l|l|l|l|l|l|l|l|l|}
\hline \multirow{2}{*}{ Commodity Code } & \multicolumn{2}{l}{ China } & \multicolumn{2}{l}{ Afghanistan } & \multicolumn{2}{l}{ Sri Lanka } & \multicolumn{2}{l}{ Pakistan } & \multicolumn{2}{l|}{ India } & \multicolumn{2}{l|}{ Maldives } & \multicolumn{2}{l|}{ Nepal } \\
\cline { 2 - 14 } & RCA & TC & RCA & TC & RCA & TC & RCA & TC & RCA & TC & RCA & TC & RCA & TC \\
\hline 0 & 0.41 & 0.07 & 6.94 & -0.61 & 3.62 & 0.05 & 3.05 & 0.22 & 1.58 & 0.48 & 15.47 & -0.44 & 3.94 & -0.69 \\
\hline 1 & 0.17 & -0.27 & 0.05 & -1.00 & 1.27 & -0.10 & 0.07 & -0.23 & 0.52 & 0.44 & 0.00 & -1.00 & 2.25 & -0.57 \\
\hline 2 & 0.18 & -0.88 & 5.98 & 0.91 & 0.81 & -0.28 & 0.89 & -0.70 & 1.02 & -0.40 & 0.59 & -0.95 & 0.94 & -0.85 \\
\hline 3 & 0.12 & -0.75 & 0.34 & -0.98 & 0.17 & -0.87 & 0.12 & -0.95 & 1.17 & -0.54 & 0.00 & -1.00 & 0.00 & -1.00 \\
\hline 4 & 0.06 & -0.84 & 0.00 & -1.00 & 2.29 & -0.19 & 0.55 & -0.93 & 0.77 & -0.82 & 0.00 & -1.00 & 0.24 & -0.99 \\
\hline 5 & 0.51 & -0.14 & 0.00 & -0.03 & 0.14 & -0.86 & 0.36 & -0.79 & 1.22 & -0.13 & 0.00 & -1.00 & 0.47 & -0.92 \\
\hline 6 & 1.37 & 0.49 & 1.25 & -1.00 & 1.00 & -0.58 & 3.41 & 0.23 & 2.06 & 0.10 & 0.00 & -1.00 & 3.75 & -0.66 \\
\hline 7 & 1.28 & 0.22 & 0.00 & -0.39 & 0.17 & -0.77 & 0.44 & -0.94 & 0.45 & -0.30 & 0.01 & -1.00 & 0.02 & -0.99 \\
\hline 8 & 2.04 & 0.63 & 1.30 & -1.00 & 3.96 & 0.68 & 2.21 & 0.59 & 1.19 & 0.45 & 0.00 & -1.00 & 1.32 & -0.54 \\
\hline 9 & 0.02 & -0.95 & 0.00 & -0.52 & 0.00 & -1.00 & 0.00 & -0.86 & 0.50 & -0.71 & 0.00 & -1.00 & 0.01 & -1.00 \\
\hline
\end{tabular}

\section{2) Trade Competitiveness Index}

TCI is defined as the ability of an industry or a country, to export more in value added terms than it imports. It is a powerful tool for setting international trade targets, detecting patterns, and can also help with diagnosing causes across levels.

$$
\mathrm{TCI}=\frac{\text { EXit }- \text { IMit }}{\text { EXit }+ \text { IMit }}
$$

TCI can be used to determine whether one country's commodity has international competitive advantage compared to the one that are supplied by the other country. If TCI $>0$, it indicates that the goods productivity is higher than the international standards. The closer to 1 , the greater the trade competitive advantage is and vice versa.

From the calculation shown in Table 4, China's primary goods' TCs in 2015 are negative except in commodity 0,

First, the strong international competitiveness in manufacturing provides a breakthrough point in which is an indication of trade deficit as a result huge demand of resources, energy and materials. In the manufacturing industries, especially in labor intensive industries (6 and 8), China's TC is more than 0.5 , which shows has a strong international competitiveness. It is noted that in capital intensive industry 7, China's TC is positive. In contrast, for the South Asia countries, the positive TCs exist in agriculture goods and labor intensive industries.

\section{CONCLUSION}

From the above analysis, it is concluded that the manufacturing industry has been a main driving force to strengthen China's international competitiveness. South Asia countries have a relative high competitiveness in agriculture and labor intensive industries. When implementing the international capacity cooperation, the following approaches should be taken into consideration.

transformation and upgrading of the industrial structure in China. The 8 countries in South Asia are emerging economies, 
which have weak industrial base and backward infrastructure. Relying on the strong advantage of China's manufacturing industry, those capital intensive industries such as iron and steel, nonferrous metals and high-speed rail, and labor intensive industries like textile can be transferred to the South Asia countries in "One Belt One Road", which will become the new industrial chain to lead the local economies. When the new production network and consumer market formed, it will in return strengthen China's international advantage and industrial influence, which will make us have a strong international disclosure power in economic cooperation.

In additional, in the industries those South Asia countries have high competence, such as agriculture, food, beverages and tobacco, "China technology" + "natural resource and labor-based" approach can be adopted to strengthen each other's short stave. In this way, it will further optimize the trade structure, create the new trade growth point, and realize a win-win situation.

To solve the overcapacity of China's tradition industry is an important economic goal in the "One Belt One Road" strategy, while international capacity cooperation is the breakthrough point, which will ultimately realize the industrial complementary and cooperative development.

\section{ACKNOWLEDGMENT}

I would like to extend to sincere thanks to my $\mathrm{PhD}$ supervisor Dr. Liu Ersi, who give his insights on the topic selection of this paper and provide guidance through the review process. And also thanks to the reviewers who provide constructive feedbacks to this paper.

\section{REFERENCE}

[1] B. Jin, G. Li, and Z. Chen, "An Empirical Analysis on Internationa Competitiveness of China Manufacturing since WTO Accession," China Industrial Economy, vol. 233, 2006, pp. 5-14.

[2] C. Pei, L. Wang, "International Competitiveness: Concept Formulation and Analytical Measurement," China Industrial Economy, vol. 169, 2002, pp. 41-45.

[3] Schott, and K. Peter, "The Relative Sophistication of Chinese Exports,' Economic Policy, vol. 23, 2008, pp. 46-49.

[4] X. Xia, "The Formation of International Capacity Cooperation Mechanism and Policy System under 'One Belt and One Road',' International Trade, vol. 2015, 2015, pp. 26-33.

[5] T. Yang, Z. Li, and Y. Zhang, "The Characteristics and Prospects of China's Foreign Investment under the New Norm," Journal of Economic Cooperation, vol. 2016, 2016, pp. 28-37.

[6] H. Yin, and J. Pan, "Issues and Countermeasure of Guangxi in Promoting International Production Capacity Cooperation under the Background of 'the Belt and Road'," Around Southeast Asia, vol. 2016, 2016, pp. 60-62.

[7] D. Zhao, and B. Sang, "International Capacity Cooperation on 'One Belt and One Road'-Based on the Empirical Analysis of International Competitiveness," Journal of International Trade, vol. 2016, 2016, pp. $3-14$ 